\title{
SMALL BUSINESS - ALTERNATIVE TO UNEMPLOYMENT REDUCTION IN ECONOMY UNDER RECESSION
}

\author{
PhD Trajković Svetlana, Collage of applied professional studies, Vranje, Serbia
}

PhD Trajković Predrag, Mapro, Vranje, Serbia

MSc Milan Ivanković, Ministry of Agriculture, Forestry and Water Management, Department for rural development, Belgrade, Serbia

\begin{abstract}
The decade long trend of unemployment rate increase, reduction of national income and salaries of the employees and demand reduction implies the necessity for taking urgent measures and counteracting the high inflation rate in order to reduce the unemployment of both the younger population as well as the elderly population (older than 50) which is often considered to be unneeded. More active initiation of small business through entrepreneurship, even self-employment can be an impetus for healing the economy.

Education, financial support in the form of favorable loans together with the fiscal policy of new entrepreneurs can initiate entering into business of people with the feeling, awareness and readiness for innovative work and uncertainty, and those who are ready to face the risk of anticipating future developments and market turbulences which are inevitable companions of modern business.
\end{abstract}

Key words: recession, small business, unemployment, national income, salary, inflation, entrepreneurship, business risk, fiscal policy

\section{Introduction}

The transition together wit all the side effects, which accompanied the economy of our country (economic isolation, hyperinflation, dirty, unfair and inefficient privatization, tycoonisation etc.) totally destroyed our economy and economic system, so that we are returned to the economic level of the prior decades in an economic sense. Our economy is nowadays fully economically devastated, with permanent decline in gross domestic product paired with recession.

The Western Balkans faced new recession in 2012, with the largest decline of 2.5 percent expected to target Serbia, while the recovery will be fairly slow in 2013, according to the World Bank statement. Debt levels are too high in some countries. Moreover, the level of our economy is comparable to the economies of Albania and Montenegro, which means that the debt is in
Montenegro, Serbia and Albania is reaching a very dangerous level, especially in Albania where it equals 60 percent of gross domestic product, although it is rapidly growing in Serbia and Montenegro. World Bank forecasts for Serbia are the most pessimistic, because our country has difficulties in stimulating growth at a time when it seeks to cut its growing budget deficit. Interview with the coordinator of the World Bank for the Western Balkans, Reuters Agency: Jane Armitage 06/11/2012/ ${ }^{1}$

The situation in our economy and the whole society indicates a turning point, which has only two options (to stop further deterioration of our economy and turn the curve in the direction of the progression of GDP, decreasing the level of indebtedness, reducing the budget deficit by reducing unemployment or otherwise to experience bankruptcy).

Small business development through entrepreneurship makes one of the powerful segments, which can stop further deterioration of the economy, increase in production, development of services directed to meeting the needs of consumers, discovery and development of new demand, and surely employing the new population with entrepreneurial visions, as well as motivating the young people to awake their business inclination for which they were even not aware of.

Our country has significant natural and human resources at disposal, although they are quite destroyed in technical sense but this is enough, if there is political will and readiness of some departments to streamline the functioning of national institutions for the

${ }^{1}$ http://www.studiob.rs/info/vest.php?id=82392 
design and adoption of appropriate business policies in order to be able to use what we have and ensure cease of further economic deterioration.

\section{Entrepreneurship in business}

Entrepreneurship is an economic activity that is focused initiation; organization and business innovation with the main objective of creating new value that meet the needs of people and the resulting profit. Entrepreneurship is open to all areas and spheres of human activity. Develops creativity, enhances developments of ideas and enriches human needs ${ }^{2}$.

Entrepreneurship is about creating new values while taking the market risks, which is full of uncertainty, in order to satisfactions the customers or users of products or services and the ultimate goal of making profit. General elements relevant to entrepreneurship observed by the means of analysis of many definitions of this economic phenomenon can be classified and expressed in the form of:

- creativity and innovation,

- identifying and gathering of resources,

- establishing of economic organization-system and creating of opportunities for profit and the acceptance of risk and uncertainty.

Entrepreneurship requires certain changes in business and management, as well as managers, and configuration of certain resources. This indicates the acceptance of the claim that entrepreneurship is present and it is reflected in the degree of change and innovations /software's, technology, resources, management/

Schumpeter suggests categorization of changes as a combination of responses to the questions:

- Has new product or service been found?

\footnotetext{
${ }^{2}$ (Penezic N. PhD - 2003.): How to become an entrepreneur - 2003.
}

- Are new methods and technologies being employed?

- Have new target markets been created?

- Have new sources of supply of raw materials and resources been used? and

- Are new forms of organizational structure being employed?

For contemporary entrepreneurial activity in the world and our business communication the term business is used, which symbolizes the individual or group business ventures meeting production or service market needs, in order to maximize profits. In theory of marketing, the acceptable concept is that the profits are result of the quality of meeting the consular needs.

In the theory of economy, such philosophy is not readily acceptable, but if one meticulously analyzes the fact that the customer is an individual investing his money in order to satisfy his/her needs, he/she will undeniably not participate in this game without personal satisfaction. This indicates that without profit there is no business.

New small enterprises emerge as an effect of entrepreneurship, and they are significant creators of new products (tangible and intangible assets that meet the needs of individuals, groups or overall economy), which can be very important in changing the people's lives. This economic activity can, should and must result in the creation of new jobs and economic structure of the system.

Entrepreneurship is usually initiated with low capital, which makes a business i.e. a small entrepreneurial activity which furthermore enables monitoring of all the factors relevant to the market hence making it very flexible, to be able to rearrange their business engagements. Small entrepreneurs, when it comes to their ability of adaptability and flexibility, their main advantage is that they make decisions ahead of time, as well as they are running first in realization, being therefore the main precursors of innovation.

History of economics points out that the world economies have always grew out economic crisis by means of entrepreneurship and small business, and therefore one should 
not ignore the opinion, that the small enterprises are the entrepreneurial engine of economic development, and even more, that this business segment promotes private ownership and entrepreneurial power readiness and ability to accept the risk which is ever present in business, but it almost always overcomes all obstacles on the road to success. The dominating opinion accepted in the economic literature which deals with entrepreneurship, is that small enterprises are synonym for the private sector and entrepreneurship. The concept of entrepreneurship development as an economic segment that at least partly solves the unemployment in a successful way and contributes to increasing of the national product, is present in Europe and worldwide, which indicates that it can be applied to Serbian case likewise.

\section{Entrepreneur and his/her traits}

Since the planning, organization and implementation of activities that need to happen in the future can not be fully foreseen, the final outcome is uncertain. Even the entrepreneur himself/herself invests own capital with no guarantee that he/she will be able to have it recovered, and certainly he/she is expecting profits from his/her own work and commitment of resources.

Creativity is reflected in the creation of ideas, design of the model for the implementation of the ideas and planning of the conceptual design for the functioning of the system. If a person wants to sail the waters of entrepreneurship only by the means of ownership transfer of a company, trying to keep the rest as a whole, there is no entrepreneurship. It can be said that this is rather change in ownership structure, which is abundant in our country, without success and with many negative effects, which constitutes one of the causes of this poor economic situation and brings the economy to the edge of bankruptcy.

Entrepreneurs are characterized by specific features, such as: possessing the tank of knowledge, skills and abilities, as well as creativity, spirit of initiative, courage, responsibility, dynamism, commitment to the business and in particular perseverance and persistence.

Several arguments indicate that entrepreneurs ought to be knowledgeable and skillful, especially in terms of entrepreneurial decision making which should not be done ad hoc, by intuition from case to case, but it should be done based on previous research and analysis of relevant factors affecting future events and market changes. An entrepreneur can not afford weak handling within his/her business sphere, which is selected and where overall resources are employed in order to achieve the set goal. It does not mean that, if an entrepreneur is a person with appropriate knowledge, that his/her career should be based on existing knowledge. He/she should continuously learn and acquire new knowledge that is up to date with technical and technological development of the society by getting acquainted to new technology. A special segment of each entrepreneur's knowledge pool allows him/her to orientate entirely on the market, which imposes the necessity to be completely aware of the market and of all the market participants. The focus of his/her interest must be people with their character traits and abilities.

Entrepreneurial knowledge and skills are an important factor in work because of:

challenges,

- easier coping the business

- entrepreneur chooses the subject of business and certainly that the focus is on what seems to be acceptable,

- entrepreneurship and entrepreneurs are present in all spheres of human society, making profit and making the driving force of human resource development (education, upbringing, providing security to partners).

The quality of entrepreneurs is a very common topic in the theory of economic analysis, and therefore we highlight Herper, who lists eight different qualities of entrepreneurs: $/^{3}$

- finders of new opportunities,

\footnotetext{
${ }^{3}$ https :/sistes.google.com/site/
} 
- focused on the future,

- constantly trying to be the best,

- market-oriented,

associates,

- know how to appreciate their

- realistic,

- diligent and accepting all sorts of jobs,

- full of life.

Education and discovering the entrepreneurial spirit

In our country, majority of entrepreneurs start the adventure of businesses by inertia, sometimes out of necessity, not knowing that they possess unique gift for business. If a person is business inclined i.e. owns skills of entrepreneurs, it often come to know by working hard usually a tedious job, that it is possible not only to survive but also to succeed in certain business job. Entrepreneur is learning through work from the basic content of business up to a level of being capable to deal with. Due to business commitments entrepreneurs do not have time to develop professionally. Paradox of entrepreneurial education is often seen here. "Majority of entrepreneurial training programmers take place at university or through informal education, while the majority of entrepreneurs are people with primary and secondary education. Entrepreneurs start to experiment and launch different ideas and business options at a very early phase in their lives because of their spirit and proactive attitude.

Each business requires time and commitment, which usually leads to the situation that many entrepreneurs do not have time for a university education and they tend to follow various courses and seminars. $/^{4}$

On the other hand it is convenient to mention that program curricula at our universities and colleges are often not based on the real needs. They have a more theoretical approach without any specific methodology for problem setting and solving.

\footnotetext{
4/www.cdop.rs/2o11/03/podsticanje preduzetnistva kroz edukaciju
}

Teachers are still practicing cabinet research rather than field research. Students learn about topics they do not truly need without being capable of recognizing elementary details. The curricula need to be adapted so as to meet the needs of specific entrepreneurship categories. We need more specialized education with specific knowledge of a certain level of entrepreneurship. It is needed to have appropriate institutions offering integral and systematic approach of introducing entrepreneurship as a subject to relevant authorities at all levels of the education system. This opinion is based on analysis of the current state of entrepreneurial education in Serbia, which is the trend of good practice in European countries, which have introduced entrepreneurship into formal education system. Hence, the government would take a strategic commitment to develop education about entrepreneurship, so that the intention of development of entrepreneurial education is consistent and logical.

If we introduce entrepreneurial education at all levels, one should expect a strong influence on the young population, by raising awareness and encouraging entrepreneurship so that entrepreneurial education could serve to individuals for starting a business, as well as it can initiate innovation and entrepreneurial values.

Education can be organized as:

- vocational training, retraining and additional training of existing staff,

- introduction of financial support programmers for entrepreneurial activities,

- establishing of institutions for the collection of information and other relevant data,

- communication with the information users in the form of information distribution,

- development and setting up of entrepreneurial schools and colleges (business schools, mostly in private hands, where quality of knowledge that leads to success should be offered and built, because the selfemployed are not going to invest capital in the short term, but their main goal would be creating the knowledge brand). 
Since we do not have the required profile of teachers in the field of entrepreneurship, it is necessary to define the same and work on teacher education for entrepreneurship.

Given the current state of our economy, it is necessary to model the system of economy based on the market economy as soon as possible, monopoly must be eliminated, and follow the laws of market. The core of the economy should be represented by privately owned small and medium-sized enterprises as a basic form, with emphasis on the rapid development of manufacturing and service industries, for which we have natural resources.

\section{Administrative support for entrepreneurship}

For many people, the motivation and interest for entrepreneurship awakes at some point, and then they initiate activities in order to find out more about entrepreneurship (from friends, reviewing literature, enrolling the entrepreneurship courses). This phase is relatively short and a decision on accepting that the activity of the business is made. Some people already have concrete ideas at this stage and they know what they want and what they are capable of, whereas a certain number of others are keen to get to work, but they are not certain about which direction to move into. What is it, what the market needs and is not covered? Can it animate the new needs of consumers which would be satisfied through its entrepreneurial activities?

Now the would-be entrepreneurs need help and free support from the community, because they are economically still not in a position to invest in the quest for ideas, the conceptual design of a business plan, i.e. a preliminary comparative analysis of income and expenses and anticipated profits, and perhaps even not the registration activities companies.

In order to solve the problem, which is expressed in the country's economic situation, it is necessary to set up agencies for animation entrepreneurship, which would be engaged in providing free services.
Community for beginners - those who are appearing for the first time to register an enterprise should have gratis the following activities:

- to regulate simplification of business registration in terms of legislation - less forms,

- to reduce as mush as possible the period from submitting the application to issuance of a permit and,

- not to limit the possibility of registration by requesting of the special conditions, which often mean ban for of entry into certain business (simply preventing competition just selectively),

- it is often happening here that entering into some business is preconditioned by requesting the profiled personnel and equipment, as if it was not clear to us that the entrepreneur, especially a beginner does not have the funds to spend unreasonably and engaging in illegal activities and therefore the business is not going to start before ensuring the quality,

- to allow and request from entrepreneurs to introduce internal self-audit in their business and to preventively control their business more frequent,

- to allow achieving of the business requirements phase by phase, where the process of activities takes place successively in stages, as there are no funds available for investing into equipment and staff, which are not likely to be used perhaps in the coming few years,

- to organize and implement preventive and more frequent control in the form of advising for beginners in entrepreneurship, certainly based on the complexity and on the social importance of the activity certain entrepreneur is engaged in (working with people, food, etc.).

Financial support of entrepreneurial business

In order to start a business, an entrepreneur needs to have several qualities in addition to personal qualities (inventiveness, 
courage, knowledge, readiness for selfsacrifice and maximum commitment), he/she also needs certain amount of financial assets, depending on the conceptual design of the activities relevant for the certain business. It is difficult to ensure all the previous conditions because of the following reasons:

- loans from friends-acquaintances are difficult to obtain because of the economic situation, there are few if any able to offer them them in various ways,

- loans from commercial banks come with a guarantee, which is usually difficult to obtain for a young entrepreneur,

- borrowing from relatives and parents is possible but often insufficient,

- alliance with friends and entering into a partnership is possible, but it is often not secure,

- funds from seling of an asset if so, which further increases the risk for young entrepreneur, but it ensures motivation for the maximum vigilance and commitment.

Initial proposal for motivating entrepreneurs in business:

- normative regulation and organization of financial support for the beginners by the institutions - agencies from the fund that should be established with the specific purpose, which may take the form of: grants, interest-free loans with a grace period of several years, loans with a favorable interest rate, competition awards for creative ideas, assistance to entrepreneurs from international funds for the development of entrepreneurship and employment, and in the case of allocation of subsidized financial resources it is necessary to establish criteria that would apply to all. Practice has shown in our country that such funds are often provided selectively, which is equal to crime, or even more that those funds are spent inappropriately.

- states must make a realistic strategy, rather than a list of pledged desires for entrepreneurship development, with established principles and sanctions if the recipient fails to comply with conditions, which are foreseen in the employment contract providing financial support for entrepreneurship, it is necessary to penalize personnel occupying positions of decision makers regarding the beneficiaries of the funds if they do not respect the principles of business established policy,

- it is necessary to have adequate control over all funds involved in the development of entrepreneurship, because the experience in the Western Balkans indicates a wrong approach to the work entrusted to them.

- the beginners should be made free of paying the administrative fees, taxes and contributions for at least for a period of three years from the moment of the business start-up,

- criminal policy should be applied for those who pretends to circumvent laws by closing the existing enterprise and they are always the beginners - it is a crime,

- customs policy should be used to motivate the business beginners.

Regardless of the fact that it is a very difficult economic situation, funds are always available for promising ideas that guarantee making profit, if a beginner in the business is not able to realize their ideas otherwise. Associations of small entrepreneurs need to be set up with the sole task of funding the good ideas and programs, which would consequently motivate young people and those able to commit to the creation of inventive ideas.

There are populations that need more help in the form of the development of social entrepreneurship and the development of women's entrepreneurship and others and this should also be noticed and regulated by law.

\section{Conclusion}

Notwithstanding the importance of small business as an entrepreneurial activity, it seems that the most responsible people do not understand the problem and the solution is 
missing for resurrection of the faltering economy and the partial resolution of unemployment reducing and the increase of the people's purchasing power.

It is evident that the appropriate authorities are aware of the situation in which the people of this country is, and that we know the importance of entrepreneurship as a proven model in dealing with the recession. Until now, much has been done to motivate these activities. Business strategies have been presented, as well as the financing and development, but the actions are not taking place. The funds, which have been obtained from the international community for this purpose, or they have been set aside in the budget, are either not properly being directed or they are often inappropriately being spent. This suggests that our society did not provide sufficient and appropriate actions by the relevant institutions to support entrepreneurship in the past. There was a very unfavorable business climate, because many institutional methods have been used to guide the activities and resources of the big companies, which have stifled entrepreneurship. In these circumstances, it is only hardly possible for the small business newcomers to start a business, but it is even harder to survive and succeed. Big companies have not perceived small businesses as manufacturers of the elements for finalization of their products, and they were solving the gap through imports and increased foreign currency demand, which consequentially caused the weakening of the value of our national currency.

Competitiveness of small enterprises is limited by the monopolistic policies of large companies and a lack of funding, just as it is also by the high costs of alimentation funding and launching of entrepreneurial activities. A particular problem is the elimination of the effects of the market, not because of the strength and quality of large companies, but because of creating such a business environment. The problem is the fact that we do not have a sufficient number of small businesses (entrepreneurs, managers) who could present their activities to financial institutions by using their skills. Even if someone knows, acts he/she independently, not being able to draw attention of the institutions to him/herself.

It is necessary to establish associations of small entrepreneurs through unions, alliances or some branch organizations, so that the joint approach draws attention of the relevant merit institutions ready to support the development of these activities while community must get to understand the importance of entrepreneurial business for the economic recovery of the country by means of its economic development strategy.

\section{Reference}

1. Klose, Alfred. Poduzetnička etika. Školska knjiga, 1996.

2. Knoblauch, Jorg. Biti poduzetnik života. Step press, 2002

3. Kolin, M. Paunovic, Z. (2007) Neprofitni sektor i socijalna preduzeća u Milan Podunavac (ed.) Godišnjak Fakulteta političkih nauka 2007, Čigoja, Beograd;

4. Leburić, Anči i Mira Krneta. Profil poduzetnika. Naklada Bošković, 2003

5. Lowe, Robin and Sue Marriott. Enterprise: Entrepreneurship and innovation. Butterworth-Heinemann, 2006

6. Moorman, Jerry W. and James W. Halloran. Successful Business Planning for Entrepreneurs. Thompson South-Western, 2006

7. Penezić N.- 2003 Kako postati preduzetnik2003.

8. www.cdop.rs/2o11/03/podsticanje preduzetništva kroz edukaciju

9. https :/sistes.google.com/si

10. http://www.studiob.rs/info/vest.php?id=82392

11. https :/sistes.google.com/site/ 